DOI: $10.33766 / 2524-0323.89 .135-148$

УДК 332.021.8

О. А. Бурбело,

доктор економічних наук, професор, заслужений діяч науки і техніки України, професор кафедри економіки та підприємництва

Інституту хімічних технологій

Східноукраїнського національного університету імені Володимира Даля

(м. Рубіжне, Україна)

e-mail: burbelo@ro.ru

iDhttps:/ / orcid.org/0000-0002-2903-9596

T. В. Патріарх, асистент кафедри економіки та підприємництва

Інституту хімічних технологій

Східноукраӥнського національного університету імені Володимира Даля

(м. Рубіжне, Україна)

e-mail: saenko.tat@ukr.net

iDhttps://orcid.org/0000-0002-2277-9073

С. О. Бурбело,

провідний економіст Інституту економіко-правових досліджень

Національної академії наук України

(м. Київ, Україна)

e-mail: ssenss82@gmail.com

iDhttps://orcid.org/0000-0002-4895-1329

\title{
ЕКОНОМІЧНА БЕЗПЕКА РЕГІОНУ В СИСТЕМІ ЙОГО СОЦІАЛЬНО - ЕКОНОМІЧНОГО РОЗВИТКУ
}

Стаття присвячена дослідженню проблем підвіщення рівня економічної безпеки регіонів в умовах реалізації реформ щодо децентралізації влади в Україні. На регіональну політику накладаються нові зобов' язання, особливо в частині підвищення рівня економічної безпеки регіонів. Зазначено, що економіка регіонів розвивалася неравномірно. Доведено, що визначення поняття «регіон» залишається дискусійним. Обгрунтовано необхідність інтегрування системи економічної безпеки в соціально-економічну систему регіону.

Ключові слова: децентралізація влади, регіональна економіка, регіон, інтеграція, нерелевантні стратегії, полярізація економічного простору.

Постановка проблеми. Реалізація реформ щодо децентралізаціії влади в Україні певною мірою гальмується відсутністю ефективної системи регіональної економічної безпеки. Необхідність формування такої системи обумовлена сучасними реаліями ведення бізнесу в країні - політична нестабільність, кризові ситуації, неузгодженність і недосконалість правової бази, відсутність науково обгрунтованої програми економічних реформ з урахуванням специфіки діяльності

(C) Бурбело О. А., Патріарх Т. В.,

Бурбело С. О., 2020 
регіонів, криміналізація економічних відносин [1, с. 46]. До цього переліку негативних чинників слід додати постійні (з 2014 р.) гібридні загрози національній безпеці держави [2].

У 2014 році, відповідно до чинного законодавства [3; 4], в Україні розпочався процес децентралізації влади, який призвів до формування об'єднаних територіальних громад (ОТГ), що повинні стати базовою складовою ефективної системи влади в державі. Як свідчить практика, створення ОТГ стикнулося з багатьма труднощами, серед яких чи не найвагомішою стала відсутність усталених пріоритетів забезпечення базових послуг населенню громад [4, с. 9]. А саме створення сприятливих умов для забезпечення мешканців ОТГ важливішими (за соціальнми стандартами) послугами є одним із завдань ефективного функціонування системи економічної безпеки регіону.

Найбільша складність у реалізації соціально-економічної політики сьогодні змістилася в регіони, через які здійснюється управління всією країною та знаходить втілення державна стратегія розвитку країни. Передача значної частини прав і відповідної їм частки відповідальності на регіональний рівень триває в руслі об'єктивних тенденцій розвитку самоврядування. Це накладає нові зобов'язання на регіональну політику, особливо в частині забезпечення економічної безпеки. Для України політика економічної безпеки в контексті регіонального розвитку до недавнього часу була політикою вирівнювання стану індустріалізації регіонів.

Аналіз останніх досліджень і публікацій. Дослідження сучасного рівня розвитку економіки регіонів України свідчить, що вона переживає не найкращі часи. Відомі вчені держави стверджують, «що ми маємо зараз справу не просто 3 катастрофічним рівнем основних економічних показників, а з якісно новим станом економіки. Новим у тому плані, що за останні кілька років вона деградувала стала «напівкримінально-тіньовою». При цьому кримінально-тіньова економіка це не якийсь окремий сектор, а підсистема, що пронизує всю економіку країни, позбавлену необхідного керуючого впливу з боку уряду. Майже всі підприємства працюють у двох сферах - легальній і тіньовій, і всі громадяни, так чи інакше, пов'язані з тіньовою економікою. Нинішня господарська система, як губка, увібрала в себе кримінально-тіньову діяльність, якою пронизано всі ланки економіки й управління [9, с. 7].

Головна причина кризового стану вітчизняної економіки - це втрата державою важелів ефективного управління економічними процесами, істотні недоліки економічної та законодавчої політики, незадовільний загальний стан господарського законодавства. Глибинна ж причина - сильний вплив на економічну й законодавчу політику ідеології ринкового фундаменталізму, проявом якого служить гасло «дозволено все, що не заборонено». За твердженням широко відомого Дж. Сороса, «ринкові сили, якщо їм надати повну владу, навіть у суто економічних і фінансових питаннях, викликають хаос в Украӥні» [10, с. 16].

На жаль, більшість виокремлених негативних наслідків від реформування економіки та суспільства не ліквідовані й сьогодні, що створює труднощі щодо забезпечення стійкого й збалансованого розвитку економіки та соціуму регіонів країни в довгостроковій перспективі [11, с. 17]. 
Питання соціально-економічної безпеки регіонів залишаються актуальними (як гарантія безпеки країни в цілому) та активно вивчаються вітчизняними науковцями, такими як: В. І. Чиж, В. К. Антошкін, В. В. Дикань, В. Ортинський, С. М. Синиця, С. В. Бєлай, Т. М. Кисла, В. І. Криленко, В. О. Ткач, А. М. Новак, Л. Л. Огарок, О. Л. Резніков [1; 11; 14; 15; 17-22 ], та низкою інших дослідників [25- 27; 33] , а також зарубіжними фахівцями, як-от: Т. Ю. Феофілова, В. К. Сенчагов, С.А.Потокіна, О.Б. Черненко, М. Е. Листопад, Е. Е. Матвєєва [16 - 32]. Вітчизняні вчені зазначають, що забезпечення інтересів країни базується на розвитку ii регіонів через реалізацію цілей і завдань у сфері регіональної соціально-економічної політики, яка віддзеркалює формування можливостей системи цілеспрямованих дій на загрози регіонального рівня [5; 9].

Водночас забезпечення інтересів країни базується на стійкому розвитку регіонів, коли реалізація цілей і завдань у сфері регіональної політики відбиває формування можливостей системи цілеспрямованих дій на загрози регіонального рівня. Однак при цьому слід враховувати регіональні відмінності рівня економічної безпеки, що визначаються нерівномірністю соціального розвитку, особливостями розвитку економіки та розміщення продуктивних сил, ступенем динамізму інноваційних перетворень, якістю людського потенціалу, інвестиційним кліматом і багатьма іншими чинниками [21, с. 1].

Більшість досліджень із проблем економічної безпеки присвячено вивченню економічної безпеки України в цілому. Тим часом соціально-економічна безпека та стійкий розвиток суб'єктів держави є основою національної безпеки. Однак розвиток регіонів перебуває на такій стадії, коли наростання старих і виникнення нових загроз безпеці стають непередбачуваними, до того ж іще не сформовано систему управління економічною безпекою регіону в складі державного механізму управління соціально-економічними процесами [27, с. 398]. Саме тому суспільно політична й економічна ситуація в Україні свідчить про кризу управління.

У державі відчувається відсутність ефективно діючої і науково обгрунтованої стратегії й тактики в діях усіх гілок влади. Подальшому розвитку окремих регіонів та держави в цілому не сприяє розбіжність між старими методами роботи й новими завданнями системи управління, місцевим самоврядуванням і ринковою економікою. Відповідно, сучасна ситуація в економіці України вимагає кардинального вирішення взаємозалежних проблем, розв' язання яких передбачає реалізацією різних заходів як на державному, так і на регіональному рівнях. Гарантування економічної безпеки і формування ефективних організаційно-економічних механізмів (ОЕМ) управління нею є одним з пріоритетних завдань у сучасних умовах розгортання кризових явищ із метою пом'якшення впливу циклічних та структурних коливань у господарському комплексі регіону [17, с. 48].

Довгостроковою метою концепції стратегії соціально-економічної безпеки регіонів України є зменшення вірогідності виникнення в певному регіоні держави кризових явищ соціально-економічного характеру $[6 ; 8 ; 13 ; 15 ; 17 ; 18 ; 21 ; 25 ; 26]$. Основними пріоритетами концепції стратегії соціально-економічної безпеки є діяльність органів державної влади та місцевого самоврядування щодо недопу- 
щення виникнення в регіонах гострих соціальних конфліктів. Не менш важливими завданнями залишаються забезпечення ефективного соціального захисту населення, умов для збільшення рівня народжуваності та зменшення рівня смертності населення в регіонах, формування середнього класу, зменшення майнової диференціації; зниження рівнів злочинності та безробіття серед населення тощо $[17$, c. 51].

За свідченням деяких авторів, унаслідок реалізації нерелевантних стратегій, не відбулося якісного зростання регіональних економік [23, с. 15; 26]. Більшість регіонів України, хоча й мали загальну позитивну тенденщію ефективності реалізації стратегії розвитку, але вона виявилася нестійкою. Це стримувало створення нових просторових форм організації економіки та зменшувало обсяги й темпи залучення інвестищій.

Упродовж останніх десяти років економіка вітчизняних регіонів розвивалася нерівномірно. Мало місце неефективне використання наявного виробничого та управлінського потенщіалу регіонів. Причиною цьому стала часта зміна цілей і напрямів розвитку, відсутність системи критеріїв, за допомогою яких можна розробляти та реалізовувати стратегії розвитку [23, с. 15]. В управлінні всіма регіонами переважали поточні та оперативні рішення, які здійснювалися з урахуванням короткострокових цілей та майже повної відсутності певної лінії стратегічної поведінки. Крім того, у недалекому минулому успішність соціально-економічного розвитку регіону багато залежала від того, представники якої території, так би мовити, були при владі: «дніпропетровські», «донецькі» чи «вінницькі».

Результати досліджень сучасного стану економічного розвитку регіонів України дозволяють зробити висновок про необхідність зміщення акцентів у регіональній політищі 3 територіальної концентрації, надмірність якої є причиною поляризації економічного простору в бік економічної концентрації [23, с. 15 ].

Формулювання цілей. Метою статті є дослідження теоретичних засад системи забезпечення економічної безпеки та інтегрування ії в соціально-економічну систему регіону.

Виклад основного матеріалу. Результати моніторингу соціально-економічного розвитку регіонів України 2017-2018 років за всіма напрямами свідчать, що серед них у першій трійці перебувають відповідно м. Київ, Рівненська та Харківська області, а серед аутсайдерів (з 23 по 25 місця) опинилися Чернігівська, Донецька та Луганська області [12]. За останні десять років ситуація з лідерством та останніми місцями серед регіонів України (за показниками соціально-економічного розвитку) досить мінлива. На жаль, вітчизняною наукою, законодавцями не запропоновані ефективні інструменти зниження диференціації рівнів соціально-економічного розвитку регіонів.

Результати дослідження організації економіки регіону та доцільності впровадження новітніх просторових форм з урахуванням стратегічних цілей і конкурентних переваг регіонів свідчать, що нині відбувається зміна парадигми розвитку продуктивних сил та відповідний злам понять щодо їх організації. На зміну територіально-часовій парадигмі дослідження продуктивних сил і поняттю «те- 
риторіальна організація економіки регіону» приходить просторово-часова парадигма та відповідне їй поняття «просторова організація економіки регіону» $[23$, c. 10$]$.

Дослідники стану економічного розвитку регіонів України за останні десять років підтверджують необхідність зміщення акцентів у регіональній політиці 3 територіальної концентрації, надмірність якої є причиною поляризації економічного простору, у бік економічної концентрації [14; 17; 18; 20; 21; 23]. Примітним у наукових публікаціях є й інший факт: поняття «безпека» відокремлюється від «стійкого розвитку».

Як і всяка система, система економічної безпеки є сукупністю елементів, що функціонують, як єдине ціле. Розгляд поняття «економічна безпека» виявив відсутність їі однакового розуміння. Відсутність єдиної думки властива і визначенню суті й структури системи економічної безпеки. Причому аналіз робіт показав, що серед численних висловлювань, які торкаються досліджуваної теми, лише незначна частина містить явний розгляд системи економічної безпеки, її складових. Часто автори просто відходять від визначення структури елементів системи економічної безпеки.

Поняття «регіону» $\mathrm{i}$ «соціально-економічної системи» багатьма авторами розуміється по-різному. Така ситуація пояснюється багатоаспектністю змісту цього поняття й неоднозначністю підходів. Це зумовило виникнення різних трактувань понять «економічна безпека» стосовно регіонального рівня. У літературі взагалі використовуються два терміни - «безпека регіону» («регіонів») і «регіональна безпека» [11; 14-17; 19; 21; 29-31].

За результатами критичного аналізу думок різних дослідників проблем економічної безпеки слід виділити найбільш вагому позищію щодо розкриття іiі поняття [16, с. 158]. Відповідно до неї, економічна безпека регіону є оціночною категорією. Вона характеризує стан соціально-економічної системи регіону. У подальшому під системою економічної безпеки розуміємо сукупність сил і засобів, спроможних своєчасно виявляти загрози соціально-економічній системі регіону й протидіяти їм. При цьому забезпечуються соціальні стандарти населення.

Мета системи економічної безпеки регіону полягає в досягненні певного рівня розвитку його економіки за допомогою формування сприятливих умов і чинників.

Окремі автори звертають увагу на економічну безпеку регіону як складову соціальної безпеки, тобто остання розглядається ними, як субкатегорія, що взаємопов'язана із економічною безпекою регіону (ЕБР) [25, с. 40], тому часто використовується словосполучення «соціально-економічна безпека регіону».

Економічною основою соціально-економічної безпеки регіону є територіальна організація виробництва, яка виявляеться в економічних процесах та явищах, що пов'язані з ринковим розвитком господарства регіону та його інфраструктурними ознаками [11, с. 21].

В Україні нині відсутній спеціальний закон, який регулює питання адміністративно-територіального устрою, залишаються не визначеними порядок створення, ліквідації адміністративно-територіальних одиниць, населених пунктів, чіткі повноваження органів влади у відповідній сфері тощо. У той же час 
продовжує діяти Указ Президії Верховної ради Української РСР № 1654 X «Про порядок вирішення питань адміністративно-територіального устрою Української РСР» від 12 березня 1981 р., більшість норм якого суперечать Конституції України. Кабінет міністрів України (27.12.2019 р.) схвалив законопроект, який визначає основні принципи адміністративно-територіального устрою України, порядку утворення, ліквідації, встановлення і зміни меж адміністративно-територіальних одиниць і населених пунктів.

Законопроект дає визначення адміністративно-територіального устрою і залишає три рівні системи адміністративно територіального устрою: базовий, субрегіональний (районний), регіональний (обласний). При цьому передбачено, що районний рівень має бути більш упорядкований і відповідати європейським стандартам.

Також у проекті закону є визначення адміністративно-територіальної одинищі й адміністративно-територіальних одиниць усіх рівнів: громада, район, регіон. $\mathcal{~ н а д і я , ~ щ о ~ з ~ п р и и ̆ н я т т я м ~ В е р х о в н о ю ~ Р а д о ю ~ У к р а і ̈ н и ~ в і д п о в і д н о г о ~ З а к о н у ~}$ наведене вище протиріччя буде скасовано.

Огляд поняття «регіон» у наукових та експертних роботах проводився неодноразово $[5 ; 7 ; 9 ; 11 ; 14 ; 16 ; 17-21 ; 29 ; 30 ; 32]$, тому обмежимося лише висновками, отриманими в результаті аналізу позищій різних авторів. Дослідники цієї проблеми в цілому визначають межі поняття «регіон» відповідно до сфери свого дослідження. Дещо складнішою є справа у визначенні регіону в економіці. У наукових публікаціях даний термін часто вживається разом із поняттями «район», «агломерація», «територія», «територіально-виробничий комплекс», «частина континента» тощо. Слід погодитися 3 точкою зору, що регіон із позищій забезпечення його економічної безпеки повинен розглядатися як елемент єдиного простору на умовно відособленій території, що має стійкі економічні зв'язки й систему органів та інститутів, які їх регулюють [16].

Підсумовуючи викладене, зазначимо, що поняття «регіон» може трактуватися з різних точок зору, а також з урахуванням історичного минулого: тобто, 3 одного боку, ідеться про частину великої географічної, культурної та політичної спільності, з іншого - визначається спільність економічних та структурних ознак. Ключовим елементом є територіальна цілісність, територіальна одиниця або територіальне об'єднання.

Розширене трактування категорії «регіон» зумовлюється не тільки авторським розумінням цієї дефініції. Вона може мати різну природу - географічну, економічну, екологічну, адміністративно-територіальну, історико-етнографічну, соціологічну тощо. Це створює можливості щодо розширення методологічних меж дослідження їі сутності.

3 викладеного можна зробити висновок про те, що регіон є не тільки підсистемою національної економіки, а й відносно самостійною його частиною із замкнутим циклом відтворення, особливими формами прояву стадії відтворення й специфічним протіканням процесів розвитку.

Якщо розглядати в якості єдиного простору країну, то під регіоном розумітимемо певну територію України, оскільки жодне інше адміністративне утворення або ж формування не відповідає вище сформульованим умовам. Звідси 
виходить, що економіка регіону - це економіка певної території держави, що має загальні риси соціально-економічної системи, об'єднуючи частини цієї території в один просторовий комплекс.

Зокрема вбачається спільність із підходом до дослідження регіону як соціуму (спільності людей, що живуть на певній території), у рамках якого висувається на перший план відтворення соціального життя (населення й трудових ресурсів, освіти, охорони здоров'я, культури) і розвиток системи розселення, де дослідження ведеться в розрізі соціальних груп із їх особливими функціями та інтересами $[16$, c. 151$]$.

Можна підсумувати, що питання визначення поняття «регіон» в українській науці залишається дискусійним, а науковий пошук у цьому напрямі триває. Однак, на превеликий жаль, у нормативно-правовій базі України немає узгодженості щодо розуміння поняття «регіон», що ускладнює роботу над розробленням концептуальних підходів до реформи адміністративно-територіального устрою України. Очевидно, це питання могло би бути вирішене з прийняттям у майбутньому Закону України «Про адміністративно-територіальний устрій України».

Стратегією економічної безпеки України виділені об'єкти економічної безпеки України - особистість, суспільство, держава й основні елементи економічної системи, включаючи систему інституціональних відносин при державному регулюванні економічної діяльності [6]. Особливий інтерес у закріплених об'єктах економічної безпеки становлять «основні елементи економічної системи». Серед них найчастіше називають соціально-економічні відносини. Вони розвиваються в кожній економічній системі відповідно до різних форм власності та економічних ресурсів і результатів господарської діяльності [7]. Тому при дослідженні проблем формування систем економічної безпеки на регіональному рівні виникає питання про доцільність ії інтеграції в соціально-економічну систему регіону. Такий крок дозволить подолати домінування надрегіональних інтересів, з одного боку, а з іншого - мінімізувати відтворення в регіоні негативних впливів, що впливають на національну безпеку [16, с. 325].

У подальшому дослідженні ми поділяємо точку зору, що в контексті розвитку соціально-економічних систем «регіон» необхідно розглядати як елемент єдиного простору на умовно відокремленої території зі стійкими економічними й соціальними зв'язками, системою органів й інститутів, які їх регулюють. Економічна безпека регіону має специфічні відмінності, які головним чином обумовлені тісним зв'язком економічних відносин із соціальним середовищем даної території. Соціальний аспект є визначальним в оцінщі стану економічної системи адміністративно-територіального утворення [16, с. 247].

Відмінними ознаками регіону від інших утворень $є$ локалізація повноважень щодо формалізованого регулювання соціальних та економічних відносин. Припускаючи економічну безпеку підсистемою соціально-економічної системи регіону, можна виділити один із елементів ії цільової функщії - забезпечення соціальних і економічних гарантій населенню в рамках певних стандартів. Цей елемент дозволяє врахувати специфіку регіонів. Відповідно до вище наведених міркувань, було сформовано модель системи соціально-економічного розвитку регіону з інтегрованою до неї підсистемою економічної безпеки. 


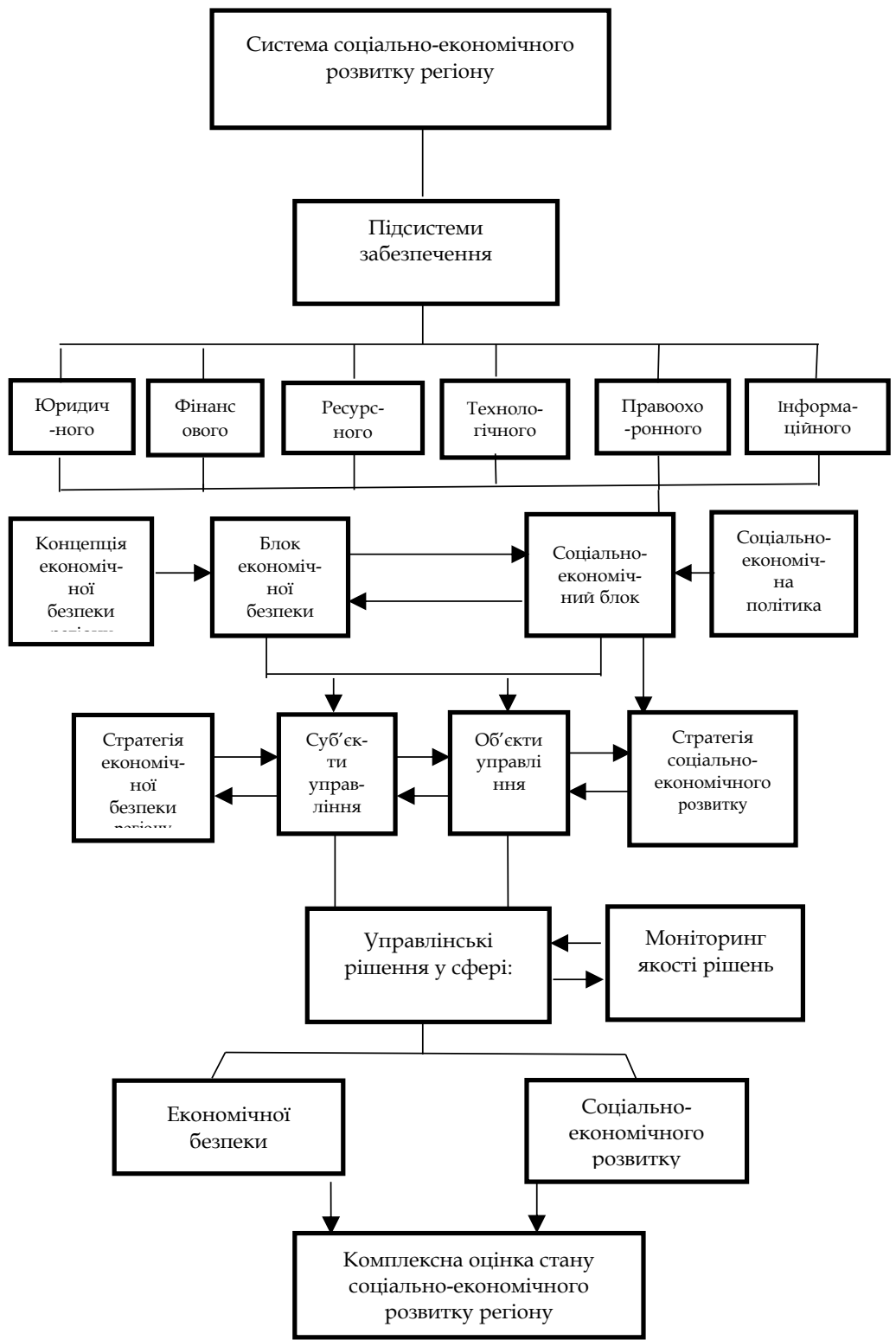

Рис. 1. Модель економічної безпеки регіону в складі системи його соціально-економічного розвитку 
Функціонування системи соціально-економічного розвитку регіону базується на шістьох підсистемах забезпечення, серед яких, на наш погляд, однією з найважливіших є підсистема правового забезпечення. Особливе значення цієї підсистеми обумовлено важливістю нормативно-правових актів України, що регламентують поведінку учасників соціально-економічних відносин [15, с. 6].

Ключовими елементами соціально-економічної системи виступають такі:

- відносини між економічними агентами й соціальними групами, індивідуумами в процесі задоволення їх потреб (у соціально-економічних відносинах);

- економічні відносини - відносини між економічнимі агентами в процесі виробнищтва та обігу;

- управлінські відносини - відносини між органами влади різних рівнів, органами влади та економічними агентами, сощіальними групами та їх індивідуумами в процесі регулювання соціальних, економічних або соціально-економічних відносин [16, c. 247].

Зміцненню економічної безпеки регіонів може сприяти вдосконалення державного регулювання економічного зростання шляхом розробки концептуальних і програмних документів міжрегіонального та територіального планування, створення комплексної системи контролю над ризиками [11].

Ідеться про заходи саме господарсько-правові, про вплив економічний або економіко-правовий, а не про посилення заходів кримінально-правових, застосованих силовими структурами. Пропонується впливати зсередини системи господарських зв'язків, а не ззовні господарського обігу [9, с. 7].

Висновки. Досвід соціально-економічного розвитку України демонструє, що реалізація реформ у різних сферах життя відбувається незадовільними темпами. Причинами цього є прорахунки в регіональній політищі держави, істотні недоліки в економічній та законодавчій політиці, відсутність ефективної системи управління економічною безпекою регіонів та конщепщії ії соціально-економічної безпеки. Подолати цей стан пропонується шляхом формування та запровадження сучасної стратегії соціально-економічної безпеки регіонів України, яка б ефективно сприяла зменшенню вірогідності виникнення в них кризових явищ. Пропонується досліджувати систему соціально-економічного розвитку регіонів крізь стійкі зв' язки учасників соціальних та економічних відносин. 3 метою підвищення ефективності функціонування регіональної системи економічної безпеки доцільно розглядати ії як підсистему соціально-економічної системи регіону.

Використані джерела:

1. Антошкін В. К. Сутність соціально-економічної безпеки регіонів та їі зв'язок з національною безпекою держави. В. К. Антошкін. Економіка та управління національним господарством: Вісник Бердянського університету менеджменту і бізнесу. 2014. № 3 (27). С. 17- 23.

2. Ахромкін Є. М., Бурбело О. А., Алексеєва А. С., Заблодська Д. В. Економіко - правове забезпечення стратегічного розвитку новоутворених територіальних громад: до обговорення. Економіка та право. № 2 (44). 2016. С. 9-13.

3. Бєлай С. В. Конщепщія стратегії соціально-економічної безпеки регіонів Украӥни. URL: http://www.kbuapa.kharkov.ua/e-book/db/2012-2/doc/2/04.pdf (дата звернення 08.02.2020).

4. Економічна безпека підприємства в умовах рейдерських загроз за наук. ред. О.А. Бурбело, С. К. Рамазанова. Севєродонецьк: Вид-во СНУ ім. В. Даля. 2015. 282 с. 
5. Закон України «Про засади державної регіональної політики» від 5 лютого 2015 року № 156-VIII. URL: zakon2.rada.gov.ua/laws/show/156-19 (дата звернення 04.02.2020).

6. Закон України «Про основи національної безпеки України» від 19 червня 2003 року № 964-IV (зі змінами та доповненнями). URL: www.rada.gov.ua (дата звернення 07.02.2020).

7. Кисла Т. М. Сучасний стан організаційно-економічного механізму забезпечення економічної безпеки регіону. Т М. Кисла. Вісник Сумського аграрного національного університету, серія «Економіка і менеджмент», вип. 6/2 (49). 2011.

8. Криленко В. І. Економічна безпека регіону як складова забезпечення національної економічної безпеки: автореф. дис. к. п. н.: 08.01.01. В. І. Криленко. Київський національний економічний університет ім. В. Гетьмана. Київ. 2006. 38 с.

9. Листопад М. Е. Эволюция представлений об экономической безопасности. Теория и практика общественного развития. 2011. № 3. URL: http://cyberleninka.ru/article/n/evolyut siyapredstavleniy-ob-ekonomicheskoy (дата звернення 04.02.2020).

10. Мамутов В. К. Передовой опыт регионализации государственного управления экономикой. Економіка та право. № 2 (44). 2016. С. 3-8.

11. Мартинюк В. Гібридні загрози Україні і суспільна безпека. Досвід СС і східного партнерства. Київ. 2018. 106 с.

12. Матвеева Е. Е. Механизм обеспечения экономической безопасности региона. Вестник Московского университета МВД России. 2018. (6). С. 282-288.

13. Механізм забезпечення економічної безпеки регіону: сутність, складові, напрями діï. В. В. Дикань, О. Ю. Александрова. Вісник економіки транспорту і промисловості. URL: http://nbuv.gov.ua/UJRN/Vetp_2017_58_4 (дата звернення 02.02.2020).

14. Моніторинг та оцінка соціально-економічного розвитку: URL http:/ / www. Minregion.gov.ua/wp-content/uploads/2018/05/Reytingova-otsinka-za-2017-rik-prezentatsiynimateriali.pdf (дата звернення 02.02.2020).

15. Новак А. М. Економічна безпека регіону: глобалізаційний вимір. URL http:// nauka.kushnir.mk.ua/ (дата звернення 02.02.2020).

16. Огарок Л. Л. Системний підхід до управління економічною безпекою як регіональної складової державного змісту. Л. Л. Огарок. Вісник Сумського аграрного національного університету, серія «Економіка і менеджмент», вип. 3. 2009.

17. Ортинський В. Аналіз нормативно-правової основи забезпечення економічної безпеки. В. Ортинський. Вісник Національного університету «Львівська політехніка». Юридичні науки. 2016. № 855. C. 4-12. URL: http:/ / nbuv.gov.ua/UJRN/ (дата звернення 06.02.2020).

18. Потокина С. А., Бочарова О. Н., Ланина О. И. Сущность и механизмы обеспечения экономической безопасности региона. Социально-экономические явления и процессы. 2012. № 3 (037). С. 83-93.

19. Принщипи економічної безпеки, ïi структура та рівні. URL: http:/ / pidruchniki.ws/ (дата звернення 10.02.2020).

20. Про добровільне об’єднання територіальних громад Верховна Рада України; Закон від 5 лютого 2015 року № 157-VIII. URL: http:/ / zakon3.rada.gov.ua/laws/show/157-19 (дата звернення 08.02. 2020).

21. Про затвердження методики розрахунку рівня економічної безпеки України: Наказ Міністерства економіки України від 2.03.2007 № 60. URL: http:/ / www/expertua (дата звернення 02.02.2020).

22. Про співробітництво територіальних громад Верховна Рада Украӥни; Закон від 17.06.2014 № 1508-VII. URL: https:/ / zakon.rada.gov.ua/laws/show/1508-18 (дата звернення 08.02.2020).

23. Резніков О. Л. Забезпечення соціально-економічної безпеки регіону - нагальне завдання сьогодення. URL: http:/ / dspace. nbuv.gov.ua/ (дата звернення 02.02.2020). 
24. Синиця С. М., Бринзей Б. С. Економічна безпека регіону як важливе завдання стратегічного розвитку. Вісник Прикарпатського університету. Економіка. 2014. Випуск Х. С. 48-51.

25. Сорос Дж. Кризис мирового капитализма. Дж. Сорос. М.: ИНФРА-М, 1999. 262 с.

26. Стратегия национальной безопасности Украины ВР Украины Закон от 21.06.2018 № 2469-VIII.

27. Стратегія забезпечення економічної безпеки України (Економічна політика). URL: http:/ /library.if.ua/ (дата звернення 03.02.2020).

28. Ткач В. О. Економічна безпека України в регіональному вимірі. Бюлетень Міжнародного Нобелівського економічного форуму. 2011. № 1 (4). С. 398-403.

29. Тяжкороб I. В. Інвестищійне забезпечення стратегії розвитку просторових форм організації економіки регіону. Автореф. дис. д-ра екон. наук. Сєвєродонецьк.: СНУ ім. В. Даля. 2018. 36 c.

30. Феофилова Т. Ю. Экономическая безопасность в обеспечении развития социально-экономическойсистемы региона: теория и методология. Специальность 08.00.05. Дис. д-ра экон. наук. Санкт-Петербург. 2014. 418 с.

31. Черненко О. Б. Экономическая безопасность региона: определение и методологические подходы к обеспечению. Вестник Ростовского государственного экономического университета (РИНХ). 2015. № 4 (52). С. 113-119.

32. Чиж В. І. Податкове адміністрування як спосіб забезпечення економічної безпеки регіону. Економіка та право. №2 (44). 2016. С. 46-52.

33. Экономическая безопасность России: Общий курс: Учебник.Под ред. В. К. Сенчагова. М.: Дело, 2005. С. 55.

\section{References:}

1. Antoshkin, V. K. (2014) Sutnist sotsialno-ekonomichnoi bezpeky rehioniv ta yii zv'iazok z natsionalnoiu bezpekoiu derzhavy. V. K. Antoshkin. Ekonomika ta upravlinnia natsionalnym hospodarstvom: Visnyk Berdianskoho universytetu menedzhmentu i biznesu-Bulletin of Berdyansk University of Management and Business, 3 (27), 17-23. [in Ukrainian].

2. Akhromkin, Ye. M., Burbelo, O. A., Aleksieieva A. S., Zablodska, D. V. (2016) Ekonomiko - pravove zabezpechennia stratehichnoho rozvytku novoutvorenykh terytorialnykh hromad: do obhovorennia. Ekonomika ta pravO-Economics and law, 2 (44), 9-13. [in Ukrainian].

3. Bielai, S. V. Kontseptsiia stratehii sotsialno-ekonomichnoi bezpeky rehioniv Ukrainy. N. d. N. p. URL: http://www.kbuapa.kharkov.ua/e- book/db/2012-2/doc/2/04.pdf [in Ukrainian]

4. Ekonomichna bezpeka pidpryiemstva v umovakh reiderskykh zahroz. (2015) O. A. Burbelo, S. K. Ramazanova. Sievierodonetsk: Vyd-vo SNU im. V. Dalia. [in Ukrainian].

5. Zakon Ukrainy «Pro zasady derzhavnoi rehionalnoi polityky» vid 5 liutoho 2015 roku № 156-VIII. URL: zakon2.rada.gov.ua/laws/show/156-19. [in Ukrainian].

6. Zakon Ukrainy «Pro osnovy natsionalnoi bezpeky Ukrainy» vid 19 chervnia 2003 roku № 964-IV (zi zminamy ta dopovnenniamy). (2019) URL: www.rada.gov.ua. [in Ukrainian].

7. Kysla, T. M. (2011) Suchasnyi stan orhanizatsiino-ekonomichnoho mekhanizmu zabezpechennia ekonomichnoi bezpeky rehionu. Visnyk Sumskoho ahrarnoho natsionalnoho universytetu, seriia «Ekonomika i menedzhment»-Bulletin of Sumy Agrarian National University, series "Economics and Management», 6/2 (49). [in Ukrainian].

8. Krylenko, V. I. (2006) Ekonomichna bezpeka rehionu yak skladova zabezpechennia natsionalnoi ekonomichnoi bezpeky. Extended abstract of candidate's thesis. Kyivskyi natsionalnyi ekonomichnyi universytet im. V. Hetmana. [in Ukrainian].

9. Listopad M. E. (2011) Evolyuciya predstavlenij ob ekonomicheskoj bezopasnosti. Teoriya i praktika obshchestvennogo razvitiya-Theory and practice of social development, 3. URL: http:// cyberleninka.ru/article/n/evolyutsiyapredstavleniy-ob-ekonomicheskoy. [in Ukrainian]. 
10. Mamutov, V. K. (2016) Peredovoj opyt regionalizacii gosudarstvennogo upravleniya ekonomikoj. Ekonomika ta pravo-The economy and right, 2 (44), 3-8. [in Ukrainian].

11. Martyniuk, V. (2018) Hibrydni zahrozy Ukraini i suspilna bezpeka. Dosvid YeS i skhidnoho partnerstva. Kyiv. [in Russian].

12. Matveeva, E. E. (2018) Mekhanyzm obespechenyia эkonomycheskoi bezopasnosty rehyona. Vestnyk Moskovskoho unyversyteta MVD Rossyy-Bulletin of the Moscow University of the Ministry of Internal Affairs of Russia, 6, 282-288 [in Russian].

13. Mekhanizm zabezpechennia ekonomichnoi bezpeky rehionu: sutnist, skladovi, napriamy dii. V. V. Dykan, O. Yu. Aleksandrova.(Eds.) Visnyk ekonomiky transportu i promyslovostiBulletin of Economics of Transport and Industry. N. d. URL: http://nbuv.gov.ua/UJRN/Vetp_201 7_58_4. [in Ukrainian].

14. Monitorynh ta otsinka sotsialno-ekonomichnoho rozvytku. N. p. URL www. Minregion.gov.ua > wp-content > uploads > 2019/05 > Reytingova-otsi [in Ukrainian].

15. Novak, A. M. Ekonomichna bezpeka rehionu: hlobalizatsiinyi vymir. N. p. N.d. URL http://nauka.kushnir.mk.ua/. [in Ukrainian].

16. Oharok, L. L. (2009) Systemnyi pidkhid do upravlinnia ekonomichnoiu bezpekoiu yak rehionalnoi skladovoi derzhavnoho zmistu. Visnyk Sumskoho ahrarnoho natsionalnoho universytetu, seriia «Ekonomika $i$ menedzhment»-Sumy Agrarian National University, series «Economics and Management», 3. [in Ukrainian].

17. Ortynskyi, V. (2016) Analiz normatyvno-pravovoi osnovy zabezpechennia ekonomichnoi bezpeky. Visnyk Natsionalnoho universytetu «Lvivska politekhnika». Yurydychni nauky-Bulletin of Lviv Polytechnic National University. Law, 855, 4-12. URL: http:/.gov.ua/UJRN/. [in Ukrainian].

18. Potokyna, S. A., Bocharova, O. N., Lanyna, O. Y. (2012) Sushchnost' i mekhanizmy obespecheniya ekonomicheskoj bezopasnosti regiona. Social'no-ekonomicheskie yavleniya i processSocio-economic phenomena and processes, 3 (037), 83-93. [in Ukrainian].

19. Pryntsypy ekonomichnoi bezpeky, yii struktura ta rivni. N. p. N. d. URL: http:// pidruchniki.ws/ [in Ukrainian].

20. Pro dobrovilne ob'iednannia terytorialnykh hromad Verkhovna Rada Ukrainy; Zakon vid 5 liutoho 2015 roku № 157-VIII. URL: http://zakon3.rada.gov.ua/laws/show/157-19. [in Ukrainian].

21. Pro zatverdzhennia metodyky rozrakhunku rivnia ekonomichnoi bezpeky Ukrainy: Nakaz Ministerstva ekonomiky Ukrainy vid 2.03.2007 № 60. URL: http://www/expertua [in Ukrainian].

22. Pro spivrobitnytstvo terytorialnykh hromad Verkhovna Rada Ukrainy; Zakon vid 17.06.2014 № 1508-VII. URL: https:/ / zakon.rada.gov.ua/laws/show/1508-18. [in Ukrainian].

23. Reznikov, O. L. Zabezpechennia sotsialno-ekonomichnoi bezpeky rehionu - nahalne zavdannia sohodennia. N. d. N. p. URL: http://dspace. nbuv.gov.ua/ [in Ukrainian].

24. Synytsia, S. M., Brynzei, B. S. (2014) Ekonomichna bezpeka rehionu yak vazhlyve zavdannia stratehichnoho rozvytku. Visnyk Prykarpatskoho universytetu. Ekonomika-Bulletin of Carpathian University. Economy, 10, 48-51. [in Ukrainian].

25. Soros, Dzh. (1999) Kryzys myrovoho kapytalyzma. Moskva: YNFRA-M. [in Russian].

26. Stratehyia natsyonalnoiyi bezopasnosti Ukrainy VR Ukrainy Zakon vid 21.06.2018 № 2469-VIII. N.p. [in Ukrainian].

27. Stratehiia zabezpechennia ekonomichnoi bezpeky Ukrainy (Ekonomichna polityka). URL: http:/ /library.if.ua/. [in Ukrainian].

28. Tkach, V. O. (2011) Ekonomichna bezpeka Ukrainy v rehionalnomu vymiri. Biuleten Mizhnarodnoho Nobelivskoho ekonomichnoho forumu. Economic security of Ukraine in the regional dimension-Bulletin of the International Nobel Economic Forum, 1 (4), 398-403. [in Ukrainian]. 
29. Tiazhkorob, I. V. (2018) Investytsiine zabezpechennia stratehii rozvytku prostorovykh form orhanizatsii ekonomiky rehionu. Extended abstract of candidate's thesis. Sievierodonetsk. SNU im. V. Dalia. [in Ukrainian].

30. Feofylova, T. Yu. (2014) Ekonomicheskaya bezopasnost' v obespechenii razvitiya social'no-ekonomicheskojsistemy regiona: teoriya i metodologiya. Doctor's thesis. Sankt-Peterburh. [in Russian].

31. Chernenko, O. B. (2015) Ekonomicheskaya bezopasnost' regiona: opredelenie i metodologicheskie podhody $\mathrm{k}$ obespecheniyu. Vestnyk Rostovskoho hosudarstvennoho ekonomycheskoho unyversyteta (RYNKh)-Bulletin of the Rostov State Economic University (RINH), 4 (52), 113119. [in Russian].

32. Chyzh, V. I. (2016) Podatkove administruvannia yak sposib zabezpechennia ekonomichnoi bezpeky rehionu. Ekonomika ta pravo-Economics and law, 2 (44), 46-52. [in Ukrainian].

33. Senchahova, V. K. (2005) Ekonomicheskaya bezopasnost' Rossii: Obshchij kurs: Uchebnik. V. K. Senchahova (Ed.). Moskva: Delo, 55. [in Russian].

Стаття надіӥшиа до редколегії 13.02.2020

\section{Бурбело О. А.,}

доктор экономических наук, профессор, заслуженный деятель науки и техники Украины, профессор кафедры экономики и предпринимательства

Института химических технологий

Восточноукраинского национального университета имени Владимира Даля (г. Рубежное, Украина)

Патриарх Т. В., ассистент кафедры экономики и предпринимательства,

Института химических технологий Восточноукраинского национального университета имени Владимира Даля

(г. Рубежное, Украина)

Бурбело С. O.,

ведущий экономист Института экономико-правовых исследований Национальной академии наук Украины (г. Киев, Украина)

\section{ЕКОНОМИЧЕСКАЯ БЕЗОПАСНОСТЬ РЕГИОНА В СИСТЕМЕ ЕГО СОЦИАЛЬНО - ЕКОНОМИЧЕСКОГО РАЗВИТИЯ}

Статья посвящена исследованию проблем повышения уровня экономической безопасности регионов в условиях реализации реформ по децентрализации власти в Украине. На региональную политику накладываются новые обязательства, особенно в части повышения уровня экономической безопасности регионов. Показано, что экономика регионов развивалась неравномерно. Доказано, что определение понятия «регион» остается дискуссионным. Обоснована необходимость интегрирования системы экономической безопасности в социально-экономическую систему региона. 
Ключевые слова: децентрализация власти, региональная экономика, регион, интеграция, нерелевантные стратегии, поляризация экономического пространства.

Burbelo O.,

Doctor of Economic Sciences, Professor,

Honored Worker of Science and Technology of Ukraine,

Professor Department of Economics and Entrepreneurship Institute of Chemical Technologies of the East Ukrainian National

University named after Vladimir Dahl

(Rubezhnoe, Ukraine)

Patriarch T.,

Assistant Department of Economics and Entrepreneurship

Institute of Chemical Technologies

of the East Ukrainian National

University named after Vladimir Dahl

(Rubezhnoe, Ukraine)

Burbelo S.,

Leading Economist, Institute

of Economic and Legal Studies

National Academy of Sciences of Ukraine

(Kyiv, Ukraine)

\section{ECONOMIC SECURITY OF THE REGION IN THE SYSTEM OF ITS SOCIO-ECONOMIC DEVELOPMENT}

The article is devoted to the study of problems of increasing the level of economic security of regions in the context of the implementation of reforms on the decentralization of power in Ukraine. New obligations are imposed on the regional policy, especially in terms of increasing the level of economic security of the regions. It is shown that the regional economy developed unevenly. It is brought up that the definition of the term "region" remains debatable. It is emphasized that Ukraine still has a by-law of the period of the Ukrainian SSR on the administrative-territorial structure of the republic, contrary to the Constitution of Ukraine. It is noted that the emphasis in the implementation of socio-economic policies is shifting to the regions. The economic security policy was a set of measures to create conditions for leveling the levels of industrialization of the regions. The state is losing the levers of effective management of the country's economy. There is a fascination with the ideology of market fundamentalism in economic and legislative activities. In regional politics, there was a frequent change in development goals and directions. Qualitative growth of the regional economy did not occur due to the implementation of irrelevant strategies. Among scientists, there are many definitions of the concept of economic security at the regional level. It is shown that the main goal of the region's economic security system should be the creation of favorable conditions for the effective development of its economy. It is proposed to study the system of economic security of the region as an integral element of the system of its socio-economic development. The necessity of integrating the economic security system into the socio-economic system of the region is substantiated. A model of economic security of the region in the structure of its socio-economic system is developed.

Keywords: decentralization of power, regional economy, region, integration, irrelevant strategies, polarization of the economic space. 